DOI:10.31696/2072-8271-2020-3-3-48-176-188

\title{
The ASEAN Economic Community in the Priorities of Japanese Companies: the Role of Singapore as a Point of Market Entry
}

\section{Evgeny A. Kanaev}

Doctor of Historical Science, Professor, HSE University, Russia, Moscow, ekanaev@hse.ru, https://orcid.org/0000-0002-7988-4210

\section{Pavel S. Shaternikov}

Teaching assistant, HSE University, Russia, Moscow, psshaternikov@edu.hse.ru, https://orcid.org/0000-0002-0856-2265

\section{Ekaterina A. Vaseneva}

HSE University, Russia, Moscow, eavasenyova@edu.hse.ru, https://orcid.org/ 0000-0002-7693-0736

Abstract: The article explores the potential of Singapore as a point of entry to the market of Association of Southeast Asian Nations (ASEAN) within the framework of the ASEAN Economic Community (AEC). Starting from an analysis of the specificity of AEC as a multilateral project, the paper proceeds with revealing the institutional links between Singapore Business Federation and AEC to finally turn to identifying the extent to which Japanese companies see Singapore's institutions as mechanisms to expand their presence to the rest of Southeast Asia. In the authors' opinion, from the ASEAN market entry perspective the potential of Singapore, for all its outstanding achievements as an area of doing business excellence, should not be overestimated.

Keywords: ASEAN Economic Community, market entry, institutions, economic initiatives, Singapore Business Federation, Japanese companies.

\section{Экономическое Сообщество АСЕАН в приоритетах японского бизнеса: роль Сингапура как точки входа на рынок}

\section{Канаев Евгений Александрович}

доктор исторических наук, профессор НИУ ВШЭ, Россия, Москва, ekanaev@hse.ru,https://orcid.org/0000-0002-7988-4210

Шатерников Павел Сергеевич

НИУ ВШЭ, Россия, Москва, psshaternikov@edu.hse.ru, https://orcid.org/0000-0002-0856-2265

\section{Васенёва Екатерина Андреевна}

НИУ ВШЭ, Россия, Москва, eavasenyova@edu.hse.ru, https://orcid.org/0000-0002-7693-0736

Аннотация: В статье проанализирован потенциал Сингапура как точки входа на рынок Ассоциации стран Юго-Восточной Азии (АСЕАН) в

(C) Evgeny A. Kanaev, Pavel S. Shaternikov, Ekaterina A. Vaseneva, 2020.

The article is the outcome of the HSE University project Doing Business in Asia-Pacific in the Age of Digital Transformations 
формате Экономического Сообщества (ЭС) АСЕАН. Рассмотрев особенности ЭС АСЕАН как многостороннего проекта, авторы статьи раскрыли специфику взаимодействия Сингапурской Федерации Бизнеса и институтов ЭС АCЕАН, закончив уточнением готовности японских компаний использовать институциональные возможности Сингапура для расширения своего присутствия в остальных странах ЮВА. По мнению авторов, несмотря на выдающиеся достижения Сингапура с точки зрения создания там условий ведения бизнеса, переоценивать его возможности как точки входа на рынок АСЕАН нецелесообразно.

Ключевые слова: Экономическое Сообщество АСЕАН, вход на рынок, институты, экономические инициативы, Сингапурская Федерация Бизнеса, японские компании

The ASEAN Economic Community (AEC) has been a trendy buzzword for almost two decades since the Association of Southeast Asian Nations (ASEAN) announced it as its key prospective project. The association declared the establishment of AEC in December 2015, and at the present point in time it remains, despite serious shortcomings, the one and only finalized initiative of economic regionalism in the AsiaPacific region.

While AEC is a welcoming development, and its new version, AEC-2025, follows the course of AEC-2015, Southeast Asia is far from being a unified production and market area integrated in the global economy. Although in the ASEAN Community Vision 2025 the AEC focus has shifted from "hard" (infrastructure) to "soft" (institutions) approach to make Southeast Asia an investor-friendly area and incentivize the corporate sector to enter and expand their presence there, obstacles are numerous. In light of this, much will depend upon the degree to which AEC can add a new value to the existing business practices.

One of them is to capitalize upon the possibilities of Singapore as a champion of doing business rankings, with strong institutions as a special point of pride and excellence. But for extra-regional companies, Singapore alone, with its 5.7 million population (as of 2019) ${ }^{1}$, fierce competition and high prices on real estate, is not commercially promising. Much more advantageous is to use Singapore as a point of entry to eventually cover the markets of other ASEAN states within the framework of ASEAN Economic Community. To specify the extent to which it is realistic is a timely and relevant exercise. 


\section{The ASEAN Economic Community: between Promise and Vulnerability}

The ASEAN Economic Community is a pivotal project initiated and developed by ASEAN as the key prerequisite for increasing its international competitiveness. The establishment of AEC was declared on December 31, 2015. Several points are noteworthy in this regard.

First, the ASEAN Economic Community was an outcome of disturbing trends which could threaten ASEAN economic prospects. After the Asian financial and economic crisis of 1997-1998, the FDI flows were shifting from Southeast Asia to China while the deficit in ASEAN member states' trade with China was conspicuously increasing. Looking forward, ASEAN feared that China's joining the WTO would further aggravate those developments. The China-proposed CAFTA along with Beijing's efforts to turn the forthcoming East Asia Summit into a Chinadriven multilateral venue added to ASEAN apprehensions. Simultaneously, APEC as the key region-wide multilateral dialogue platform focusing on economic issues turned a blind eye to ASEAN sensitivities while ASEAN partners from Northeast Asia were steadily increasing cooperation with prospects, much to ASEAN disappointment, of seizing the initiative in shaping the parameters of economic regionalism in East Asia.

These factors incentivized the association to launch the ASEAN Community in 2003, with AEC as one of its pillars. Once the association published the AEC Blueprint, new questions arose. The feasibility of one of AEC components - a single market and a single production base in Southeast Asia - can be doubted. While the substance of the single market is more or less clear since AFTA, with all its shortcomings, is a finalized project, the single production base looks like a paper exercise rather than an explicit and realistic goal.

AEC has serious inherent limitations. While the AFTA goals are achieved, non-tariff measures and infrastructure gaps sideline its merits. Since Southeast Asia is covered by supply-production chains operated by multinationals, they are far from willing to coordinate their activity with ASEAN prospective plans. In Southeast Asia, mechanisms of public-private partnership (PPP) are weak as business is reluctant to invest in long-term projects.

Infrastructure remains the key point of vulnerability. In maritime Southeast Asia, the construction of trans-national objects is hampered by the factor of geography. Port infrastructure is also poor. Assessments like "... it is cheaper to ship essential goods from China to Singapore 
than to send goods from Jakarta to Papua, both in Indonesia ${ }^{29}$ are not rare. On the Indochina peninsular, chronic financial shortages are behind the infrastructure underperformance.

More importantly, ASEAN member states differ in what infrastructure stands for, the logistics being the most revealing example. As Sanchita Basu Das and Tham Siew Yean observe, "While for Cambodia, logistics is understood as a combination of transportation infrastructure, logistics service providers, institutional frameworks and logistics users, for Indonesia it covers business activities ranging from transport and storage, post and couriers and distribution. There is no official definition of logistics for most ASEAN countries ${ }^{3}$."

At the present point in time, the infrastructure component of intra-ASEAN cooperation embraces a new dimension. An important aftereffect of US-China trade contradictions is a disruption of long-term trade practices. In these circumstances, businesses have to bear additional costs to reorganize the intra-company processes, as well as diversify their suppliers and market destinations. As Grant Thornton observed in 2019, "having multiple supply chains is more critical than ever" the emerging supply chains are mostly China-centered, to develop and secure a "China plus one" chain or even a "China plus many" network is a primary task. But a concomitant aftereffect is to obtain political support from alternative partners, which is far from guaranteed and will hardly derive a favorable response from the PRC.

Second and closely related to the first, two Master Plans on ASEAN Connectivity, adopted in 2010 and 2016 respectively, have been unable to markedly intensify economic cooperation between ASEAN member states. The first MPAC prioritized the implementation of largescale infrastructure projects which stumbled over lack of finance. According to the Asia Development Bank estimate in early 2010s, ASEAN infrastructure spending would amount to 60 billion dollars annually during the next ten years ${ }^{5}$. Coupled with lack of legal connectivity with regard to investment laws and regulations of ASEAN member states, this made the infrastructure development prohibitively long and costly.

Attempting to navigate these minefields, the second Master Plan on ASEAN Connectivity prioritized the institutional dimension of cooperation with an emphasis upon an assistance from ASEAN dialogue partners. Establishing the ASEAN Connectivity Coordinating Committee, the Committee of Permanent Representatives and the Lead Implementing Body for Sustainable Infrastructure, as well as delegating the ASEAN Secretariat more authority to shape the connectivity agenda, the 
association re-energized its policy. But most importantly, ASEAN fostered dialogue with China, Japan and South Korea in order to incentivize them to invest in Southeast Asia ${ }^{6}$. Discouragingly, however, this resulted in a politicization of the regional connectivity topic.

The most convincing evidence is provided by ASEAN-China relations. In November 2019, ASEAN and China agreed upon synergizing MPAC 2025 and the Belt and Road Initiative ${ }^{7}$. As a result, Southeast Asian industrial and commercial sector will be technologically linked to China's digital eco-system, including to the Chinese integrated solutions. More fundamentally, China's digital platforms which expand their presence in Southeast Asia may well embrace not only the B2C (business-tocustomer) but also the B2B (business-to-business) sector. Simultaneously, China's digital payment systems are scaling up. As this practice further expands, China will raise the issue of revising global technological standards. For the association, this scenario means a new escalation of Sino-US controversy over technological issues, as well as a narrowing spectrum of possibilities to maintain its digital and, more importantly, technological sovereignty.

Third, while ASEAN stakes upon the institutional connectivity, it is unable to develop strong regulatory institutions and norms. It is common knowledge that the ASEAN modality of cooperation, or ASEAN Way, has long been criticized for lack of obligatory component. At present, the situation is aggravated by lack of international regulatory framework that can be adopted to ASEAN policy. One of the minefields is the digital dimension of legal obstacles. In fact, dealing with pressing issues - be it digital advertising, on-line sales or internet enterprises - is impossible as regulations lag behind the actual practice. For instance, the "targeted effect" of digital advertising, virtual property, types of encrypted digital signature and blockchain-related commercial issues still lack the legal specification. As a result, both producers, traders and consumers face nearly a complete lack of legal protection.

The interim results of ASEAN Business Advisory Council (ASEAN BAC) are mixed at best. On the one hand, ASEAN BAC was premised upon a solid foundation since ASEAN Chamber of Commerce and Industry pioneered many projects of regionalism in Southeast Asia including ASEAN Industrial Cooperation (AICO) scheme and ASEAN Free Trade Area (AFTA). Consequently, prior to the establishment of ASEAN BAC, ASEAN leaders were aware of the limits of the possible. The fact that ASEAN BAC was established shortly before Bali Summit at which ASEAN declared its plans regarding the ASEAN Community 
signified that business was expected to play a crucial role in developing the AEC. Also, ASEAN BAC supervises numerous projects, including ASEAN Business Awards, ASEAN Business and Investment Summit, with positive implications for the corporate sector in Southeast Asia, as well as holds a direct dialogue with ASEAN partners via respective Business Councils. Revealingly, the role of ASEAN BAC is expected to increase in achieving the goals of ASEAN Economic Community $2025^{8}$.

Nevertheless, the potential of ASEAN BAC should not be overestimated. Tellingly, many industry champions consider their participation in ASEAN BAC as a secondary priority since it demands financial allocations while not generating immediate commercial feedback. In their turn, the majority of MSMEs hardly understand what AEC stands for and how it may be used to their advantage.

As a multilateral initiative, the ASEAN Economic Community is unfinished from both economic and business perspective. As P.Kotler, H.Kartajaya and Hooi Den Huan note, the key is "the challenge of managing the paradox between regionalization (regional economic integration) and decentralization (stronger role of the local government authorities)"9. In fact, local authorities know the grass-root economic and business processes, including patron-client ties, the specificity of financing companies and inter-company relations in their areas of control, etc. Subsequently, the advantage of local priorities over central and the more so trans-national, in terms of implementing economic projects and distributing their benefits, is obvious. Naturally, this suggests that local authorities are reluctant to move beyond their territorial domains. This immensely complicates the realization of even relatively easy initiatives, not to mention large-scale and financially burdensome trans-national projects.

Along with that, a relatively problem-free road to AEC generates no less significant problems. Suffice it to mention J.Pelkmans' assessment that capital flows may endanger the financial systems of ASEAN member states owing to "the risk of financial instability and the underdevelopment of ASEAN capital markets (small, initially no bond markets, no large banks in the world league, etc.)" ${ }^{\prime 10}$. Coupled with the underdeveloped standardization, customs procedures and legal protection of trans-border exchanges, the assessment that AEC 2025 may well be further extended does not appear to be ungrounded.

At this complicated crossroads, much will depend upon the practices that have been functioning for a long time and proved their validity. 
This is where Singapore with its excellent record of doing business ranking comes into a sharp focus.

\section{Bridging Singapore's Capabilities and ASEAN Institutions: a Realistic Assessment}

In the «Doing Business» list published by the World Bank, Singapore is ranked second in the world for ease of doing business and fourth in ease of starting ${ }^{11}$. Once AEC was declared, Singapore's potential advantages of scaling up businesses all over Southeast Asia became completely commensurable with the priorities of the corporate sector of ASEAN dialogue partners and multinationals.

One of Singapore's major institutions that embraces the corporate sector is the Singapore Business Federation (SBF). Its objectives are to represent, advance, promote and protect, in Singapore and abroad, the companies' policies and priorities (investment, trade, labor management, business-to-business, business-to-government issues etc.). Membership is granted to local companies with a paid-up share capital of, or above the amount of, 500,000 USD; and to foreign companies with an authorized share capital accounting for or exceeding 500,000 USD ${ }^{12}$. This suggests that SBF covers relatively large companies which can synergize their activity with the AEC priorities and participate in the AEC projects.

With regard to the latter, the Strategic Plan for Cooperation between the ASEAN Countries in the Field of Taxation, adopted in 2016, is worthy of note. The general trend of income tax has been declining over the past few years in Vietnam, Thailand, Singapore, Malaysia, Indonesia and the Philippines, which allows companies to expand their business to those countries ${ }^{13}$. Unfortunately, so far SBF does not appear to take advantage of this opportunity.

Another initiative is the ASEAN Trade Facilitation Framework. It focuses upon the customs and transport facilitation, the transparency of trade regulation and procedures, as well as upon the issues of standards and conformance, the private sector engagement and the business facilitation $^{14}$. An unstated but very important task is to improve business climate in AEC by stimulating commercial exchanges all over Southeast Asia with trade as a jumping-off place. SBF Business ASEAN network includes country divisions such as Business Vietnam, Business Thailand, Business Indonesia etc., tasked to foster collaboration and share experience among Singapore-based enterprises for expansion into ASEAN, to build up connections between the Singapore-based enterprises and the ASEAN member states' authorities, as well as to attach the ASEAN ac- 
tivities to the needs of Singapore-based enterprises ${ }^{15}$. Despite this line of SBF activity, the results obtained have been discouragingly modest so far.

The same assessment is relevant to the SBF connection to other ASEAN initiatives, for instance, the ASEAN Institutional Framework on Access to Finance for MSME, the Initiative for ASEAN Integration (IAI) Work Plan III or even ASEAN Digital Integration Framework. The institutional linkages between SBF and the AEC prospective plans to capitalize upon the possibilities of Singapore as a point of business excellence remain underdeveloped.

In sum, the extent of the SBF utility from the perspective of AEC institutions is limited. In theory, SBF provides its members with a number of advantages, such as information-sharing and building up connections which, in case properly maintained, may well be used at the appropriate time. In practice, however, the SBF possibilities cannot be immediately adjusted to the AEC prospective plans to the best advantage of the corporate sector. The experience of Japanese companies further proves this point.

\section{Evidence from Japanese Companies}

The Japanese business expansion in Southeast Asia has been notable in the decades that followed the Pacific War, further stimulated by the promulgation of Plaza agreement in 1985. Nowadays it remains one of the primary destinations of Japanese investments, as well as a base for establishing the regional headquarters (RHQs) that enable the Japanese companies to further expand to the Asia-Pacific region. In line with this priority, the afore-mentioned Singapore's record of doing business excellence has been among the key incentives.

During the initial stage of the Japanese penetration the Southeast Asian markets in the 1950s and 1960s, it was predominantly premised upon quasi-governmental keiretsu-like linkages between business groups. Since keiretsu is a type of business relations, with large multiprofile conglomerates uniting firms in various sectors by means of both formal and informal ties, the Japanese networks in Southeast Asia hinged on the same mechanisms ${ }^{16}$. For instance, Toyota had its vehicles assembled by the Indonesian Astra Group, which gained a significant market share due to its connections with Toyota, Isuzu and Daihatsu ${ }^{17}$. With a course of time, Japanese production networks in Southeast Asia were growing as local subcontractors and the Japanese enterprises diversified and solidified their linkages ${ }^{18}$. 
Later on, the Japanese MNEs started to locate their regional headquarters in the region, and Singapore became a primary point of market entry. Enabling the companies to meet the local demand and to enhance the management efficiency of the business units, regional headquarters can carry out crucial functions like monitoring the company's sales, R\&D and marketing performance ${ }^{19}$. Since recently, Japanese RHQs in Singapore have been prioritizing compliance and internal control issues. According to a poll conducted by Japan External Trade Organization (JETRO) in 2019, about $40 \%$ of surveyed enterprises (the total number was 108) stated that they were planning to expand their operations $^{20}$.

From the Japanese corporate perspective, the tendency of establishing RHQs in Singapore reached the peak in 2016 - from 90 to 108 enterprises $^{21}$. While some MNEs like Toyota had already established their RHQ in Singapore, in 2010s a new surge of interest expressed by Japanese companies was evident. For example, Panasonic transferred its logistics and procurement headquarter from Japan to Singapore in 201. A year later, Mitsui, which moved its oil department, followed this path $^{22}$. Regarding startups, the practice of their establishment in Singapore stems from the institutional factor. Unlike other ASEAN member states without efficient institutional and regulatory frameworks, Singapore provides not only tax incentives and operational convenience, but political and legal stability. For instance, the CEO of the HIPSTORES startup based in Singapore, Hiroyuki Okamoto, mentioned that "it was easier to implement capital policies as well as easy access to funds from investors", as well as pointed to the advantages of corporate tax rate ${ }^{23}$.

The growth of Japanese business presence in Singapore is reflected by the number of members of ASEAN Japanese Chamber of Commerce and Industry (FJCCIA). Embracing Japanese chambers of commerce in each country and region with the overall number of FJCCIA members reached 7,394 in 2019. Despite the number of its members located in Singapore lags behind the corresponding figures of Vietnam and Thailand, up to 2016 a gradual increase was in place ${ }^{24}$.

On the whole, the growth potential, pollical stability, welldeveloped infrastructure and efficient regulatory institutions incentivized Japan's companies to choose Singapore as a point of market entry to eventually embrace other countries. Part of this task was to build up connections with Singapore Business Federation. As an example, in 2011 Sumitomo Mitsui Banking Corporation and Singapore Business Federation signed a memorandum of cooperation on business support for 
Japanese companies expanding to Singapore ${ }^{25}$. Almost a year later, Kyukeiren, or Kyushu Economic Federation, also concluded a memorandum of understanding with $\mathrm{SBF}^{26}$. The memorandum covers resourceful initiatives like substantiating economic exchanges with human resource development by means of internship and other mutual exchange programs $^{27}$. Nevertheless, progress in developing institutional ties between Singapore and Japan has been limited so far. Suffice it to mention that in 2020 cooperation between Kyukeiren and SBF was reduced to Singapore Business Webinar event, where Kyukeiren was one of the hosts $^{28}$.

Although after the establishment of the ASEAN Economic Community in 2015 the inflow of Japanese companies reached its maximum, the subsequent trend was declining. According to the 2017 JETRO's research on the overseas development of Japanese enterprises, as a point of entry to the ASEAN, Singapore was supplanted by Vietnam, whose attractiveness for Japanese companies has been increasing for three years ${ }^{29}$. After 2015, the role of Thailand which launched several schemes to encourage foreign enterprises to establish their RHQ to the country, has become remarkable as well ${ }^{30}$.

Instead of staking upon the AEC institutions, the Japanese companies seem to benefit from the first-mover advantage since linkages between the Japanese and Singapore business associations had existed long before the journey to AEC started. Later on, this was substantiated by the Japanese government policy aimed to increase trade and investment cooperation with ASEAN member states. As factual evidence suggests, AEC alone has been unable to incentivize Japanese companies to markedly increase their presence in Southeast Asia capitalizing upon linkages with SBF and institutions provided entirely and exclusively by AEC. Tellingly, even official papers and protocols of prioritize the incomplete state of institutional development of AEC, including the AEC Blueprint to $2025^{31}$. If so, to expect a new wave of interest expressed by Japanese companies to enter the ASEAN market via Singapore is premature at best.

\section{Conclusion}

A balanced analysis of Singapore's possibilities to incentivize the corporate sector to enter the ASEAN market as part of the ASEAN Economic Community agenda reveals limited rather than exciting prospects.

Since the AEC is an unfinished project with numerous points of vulnerability, from its vision to lines of functional deficiencies, it will 
hardly be the game-changer in the perceptions of the extra-regional corporate sector to increase their presence in Southeast Asia. This scenario is realistic with regard to China which is motivated by geostrategic rather than exclusively commercial reasons. Concerning the latter, the potential of Southeast Asian market had been explored long before the establishment of AEC and by different instruments than the AEC institutions.

The empirical evidence provided by the Japanese companies substantiates this assessment. Revealingly, having established its presence Singapore long before AEC, the Japanese corporate sector takes a cautious approach to Singapore as a point of entry into the rest of Southeast Asia. Arguably, this is due to the AEC fundamental shortcomings coupled with the rising politicization of cooperation between ASEAN and its dialogue partners rather than to Singapore's underperformance.

In sum, for extra-regional companies and multinationals there is a long way to go to capitalize upon Singapore's outstanding achievements as a business excellence model. Under any scenario, the expansion of Singaporean practices to other ASEAN member states will be long, costly and fraught with numerous setbacks.

\footnotetext{
${ }^{1}$ ASEAN Member States: Key Socio-Economic Indicators 2019. ASEAN Statistical Leaflet 2020. P. 2. URL: // https://www.aseanstats.org/wp-content/uploads/2020/11/ASEAN Leaflet 2020.pdf

${ }^{2}$ The Future of ASEAN - Time to Act. PwC Growth Markets Centre. May 2018. P. 112. URL: // https://www.foundry-planet.com/fileadmin/redakteur/pdf-dateien/01pwc-gmc-thefuture-of-asean-time-to-act.pdf

${ }^{3}$ Tham Siew Yean, Das S.B. Logistics Development in ASEAN: Complex Challenges Ahead. Trends in Southeast Asia. 2018. № 1. P. 4. URL: // https://iseas.edu.sg/images/ pdf/TRS1_18.pdf

${ }^{4}$ Grant Thornton. What a Trade War means for Asia Pacific Businesses. 2019. URL: // https://www.grantthornton.cn/en/insights/1099.html

${ }^{5}$ Facts and Data about ASEAN Infrastructure. Asian Development Bank. May 3, 2012. URL: // https://www.adb.org/features/fast-facts-asean-infrastructure-fund ${ }^{6}$ Muller L. Connecting Southeast Asia - Progress under the Master Plan on ASEAN Connectivity 2025. ASEAN Briefs. 2019. Vol. 6. Issue 2. URL: // https://www.researchgate. net/publication/341684696_Connecting_Southeast_Asia_-_Progress_under_the_Master_ Plan_on_ASEAN_Connectivity_2025

${ }^{7}$ ASEAN-China Joint Statement on Synergising the Master Plan on ASEAN Connectivity (MPAC) 2025 and the Belt and Road Initiative (BRI). URL: // https://asean.org/storage/2019/11/Final-ASEAN-China-Joint-Statement-Synergising-theMPAC-2025-and-the-BRI.pdf
} 
${ }^{8}$ D.2. Strengthening the Role of the Private Sector. ASEAN 2025: Forging Ahead Together. Jakarta: ASEAN Secretariat, 2015. P. 90-91. URL: // http://setnas-asean.id/site/uploads/ document/book/599ed5208874f-asean-2025-forging-ahead-together-final.pdf

${ }^{9}$ Kotler P., Kartajaya H., Hooi Den Huan. Think New ASEAN! Rethinking Marketing towards ASEAN Economic Community. Singapore: McGraw Hill Education, 2015. P. 35.

${ }^{10}$ Pelkmans J. Understanding the ASEAN Economic Community: Pragmatism vs Conceptualism. Asia-Pacific Business Review. 2019. Vol. 25. № 5. P. 619-636. P. 623.

${ }^{11}$ Ease of Doing Business rankings // The World Bank. URL: https://www.doingbusiness. org/en/rankings.

${ }^{12}$ SINGAPORE BUSINESS FEDERATION ACT // Singapore Statute Online. URL: https://sso.agc.gov.sg/Act/SBFA2001.

${ }^{13}$ Savelyev A. A. Nalogovye aspekty investicionnogo klimata vedushchih stran // Gumanitarnye, social'no-ekonomicheskie, i obshchestvennye nauki. 2014. № 9. URL:

https://cyberleninka.ru/article/n/nalogovye-aspekty-investitsionnogo-klimata-veduschihstran-asean.

${ }^{14}$ ASEAN Trade Facilitation Framework // ASEAN. URL: https://asean.org/wpcontent/uploads/2016/08/ASEAN-Trade-Facilitation-Framework.pdf.

${ }^{15}$ SBF Business ASEAN Network // Singapore Business Federation. URL: https://www.sbf.org.sg/business-expansion/sbf-businessasean-network.

${ }^{16}$ Manifold D. L. Japanese Corporate Activities in Asia: Implications for U.S.-Japan Relations. U.S. International Trade Commission. Diane Pub Co, 1996. P. 7, 14.

${ }^{17}$ Hatch W., Yamamura W. A Looming Entry Barrier: Japan's Production Networks in Asia https://www.files.ethz.ch/isn/144711/vol8no1.pdf. P. 13.

Sato Y. Japan's Role in the Southeast Asia Automobile Industry // Forum. Vol. 14, No. 3 and 4, P. 15.

${ }^{18}$ Ibid., P. 15.

${ }^{19}$ Takahashi H. Regional Headquarters as Multinational Global Strategies // The Challenge for Japanese Multinationals. Palgrave Macmillan, London. 2013. P. 7.

${ }^{20}$ Japanese Firms Doing More Tasks at Regional Headquarters in Singapore: JETRO Poll

// NNA Business. URL: https://english.nna.jp/articles/8812.

${ }^{21}$ Japanese Firms Doing More Tasks at Regional Headquarters in Singapore...

${ }^{22}$ Hayakawa K., Shiino K. Singapore as Location of Choice as Regional Headquarters for Japanese MNEs: Strengths and Challenges // ISEAS Perspective. ISEAS - Yusof Ishak Institute. P. 2

${ }^{23}$ Iwasaki K. The Rising of Japanese Startups in Southeast Asia. RIM Pacific Business and Industries Vol. XVI, 2016 No. 62. P. 7.

24 第12回 ASEAN事務総長とASEAN日本人商工会議所連合会（FJCCIA）との対話 について (The 12th Dialogue between the Secretary General of ASEAN and the Federation of Japanese Chambers of Commerce and Industry in ASEAN (FJCCIA)) // URL: https://www.jetro.go.jp/news/releases/2019/b39d39a913342452.html;

ASEAN地域の複数国における拠点展開. 日本企業による事例を見る (Expanding Bases in Multiple Countries in the ASEAN Region. See Examples by the Japanese Companies) // URL: https://www.jetro.go.jp/biz/areareports/2018/fa79c93a51594984.html. 25 各位平成 23 年10月17日 株式会社 三井住友銀行シンガポール事業連盟との業務提 携覚書の締結について (On the Conclusion of a Business Alliance Memorandum with Sumitomo Mitsui Banking Corporation Singapore Business Federation) // URL: https://www.smbc.co.jp/news/pdf/j20111017_01.pdf. 
26 シンガポールビジネス連盟と MOU を締結〜署名式ならびに「シンガポール・九 州ビジネスフォーラム」を開催〜 (Signing MOU with Singapore Business Federation. Singapore / Kyushu Business Forum) // URL:

https://www.kyukeiren.or.jp/files/topics/achieve/160419162037342.pdf.

27 シンガポールビジネス連盟(Singapore Business Federation. Kyukeiren) // URL:

https://www.kyukeiren.or.jp/mou/?url=singapore01.html.

28 シンガポール・ビジネスウェビナー〜イノベーション最先端都市、先端技術実

験都市シンガポールの最新ビジネス事情〜を開催します (Singapore Business Webinar - Latest Business Conditions in Singapore, a City of Innovation and Advanced Technology Experiments) // URL: https://www.kyushu.meti.go.jp/press/2008/200812_1.html. $29 「 2017$ 年度日本企業の海外事業展開に関するアンケート調査」（ジェトロ海外 ビジネス調査）結果概要（"Questionnaire Survey on Overseas Business Development of Japanese Companies in 2017" (JETRO Overseas Business Survey) Summary of Results) // URL: https://www.jetro.go.jp/news/releases/2018/5f964b3f8b81717b.html.

${ }^{30}$ FY2015 Survey on the International Operations of Japanese Firms - JETRO Overseas Business Survey - (JETRO) // JETRO. URL:

https://www.jetro.go.jp/ext_images/en/reports/survey/pdf/jafirms2015.pdf.

${ }^{31}$ ASEAN 日本人商工会議所連合会（FJCCIA）について(About the FJCCIA) // URL: https://jjc.or.id/hojin/wp-content/uploads/rijikai/\%E8\%B3\%87\%E6\%96\%991-1FJCCIA\%E6\%A6\%82\%E8\%A6\%81\%E4\%B8\%80\%E6\%9E\%9A\%E7\%B4\%99.pdf.

Статья поступила в редакцию 01.12.2020, принята к публикации 10.12.2020. 